\author{
Monika Rozkrut* \\ Uniwersytet Szczeciński \\ Dominik Rozkrut** \\ Uniwersytet Szczeciński
}

\title{
UMIEJĘTNOŚCI CYFROWE JAKO CZYNNIK ROZWOJU GOSPODARKI OPARTEJ NA WIEDZY
}

\begin{abstract}
Streszczenie
Postęp w zakresie rozwoju technologii informacyjno-komunikacyjnych prowadzi do istotnych zmian w systemie społeczno-gospodarczym. Rewolucja w dziedzinie przechowywania, przetwarzania i przesyłania informacji sprawia, że odnosząc się do tego systemu, posługujemy się obecnie takimi koncepcjami, jak społeczeństwo informacyjne czy gospodarka oparta na wiedzy. Tak określaną gospodarkę cechuje wszechstronne wykorzystanie wiedzy $\mathrm{i}$ informacji. Stawia to poważne wyzwania w dziedzinie umiejętności cyfrowych, coraz bardziej pożądanych na rynku pracy, ale i coraz bardziej niezbędnych w życiu codziennym. Brak tych umiejętności, ich nieodpowiedni poziom czy niedopasowanie do potrzeb mogą stanowić istotną barierę w rozwoju gospodarczym.
\end{abstract}

Slowa kluczowe: gospodarka oparta na wiedzy, umiejętności cyfrowe, społeczeństwo informacyjne, wykluczenie cyfrowe

* Adres e-mail: monika.rozkrut@usz.edu.pl.

** Adres e-mail: dominik.rozkrut@usz.edu.pl. 


\section{Wprowadzenie}

Żyjemy w społeczeństwie dynamicznych zmian dotyczących wielu obszarów aktywności człowieka. Obserwujemy szeroki zakres przemian występujących w sferze ekonomicznej, społecznej i technologicznej związanych z przeobrażeniami w kierunku społeczeństwa informacyjnego. Zmiany te mają charakter długoterminowy i prowadzą do zasadniczego wzrostu zdolności wykorzystania wiedzy. Gospodarkę i życie społeczne opanowała technika i automatyzacja oraz ciągłe dążenie do innowacji w każdej dziedzinie. Niezmiernie ważnym elementem obecnego systemu społecznego jest koncepcja gospodarki opartej na wiedzy, tj. gospodarki, którą cechuje wszechstronne wykorzystanie wiedzy i informacji. W istocie statystyki krajów rozwiniętych wskazują, że firmy inwestują obecnie tyle w wartości niematerialne i prawne związane $\mathrm{z}$ innowacjami, ile inwestują w tradycyjne formy kapitału, jak maszyny, urządzenia i budynki. Akumulacja wiedzy to podstawowy czynnik trwałego wzrostu gospodarczego. Jest ona ściśle powiązana z nakładami na edukacje。 badania naukowe, postęp techniczny, rozwój instytucjonalny. Znaczne zróżnicowanie krajów czy regionów pod względem tempa rozwoju, wydajności, technologii jest pochodną tej akumulacji. Zadaniem polityki gospodarczej jest w tych warunkach budowa trwałych fundamentów tworzenia, absorpcji i dyfuzji innowacji, stawiając na regionalna specjalizacje wsparta wzrostem świadomości i kompetencji innowacyjnych.

Podobnie jak w społeczeństwie informacyjnym, tak w koncepcji gospodarki opartej na wiedzy ważną rolę odgrywa rozwój i rozpowszechnianie się technologii informacyjno-komunikacyjnych (ICT). Istnieje wiele badań dotyczących wpływu ICT na podstawowe agregaty ekonomiczne w skali makro i na efektywność funkcjonowania gospodarki, a w szerszym ujęciu - wpływu na zjawiska społeczne. W dużym skrócie bezpośrednim efektem ekonomicznym w dhugim okresie jest wzrost wydajności, przychodów, a co za tym idzie, wzrost produktu krajowego brutto. Pojawienie się i rozwój nowych technologii informacyjno-komunikacyjnych nie pozostają jednak obojętne dla rynku pracy. Obserwuje się rozwój nowych, bardzo istotnych, kompetencji cyfrowych, umożliwiających sprawne i świadome korzystanie z nowych technologii oraz aktywne uczestnictwo w życiu społeczeństwa informacyjnego. Celem niniejszego artykułu jest analiza roli tych ostatnich jako zasadniczego czynnika sukcesu osobistego, rozwoju gospodarki opartej na wiedzy i społeczeństwa 
informacyjnego. Osiągnięcie odpowiedniego poziomu kompetencyjnego, czyli nabycie niezbędnych umiejętności wykorzystania możliwości, jakie niosą technologie informacyjno-komunikacyjne, jest szansą dalszego, trwałego rozwoju społeczeństwa informacyjnego.

\section{Społeczeństwo informacyjne i gospodarka oparta na wiedzy}

Kolejny etap w rozwoju społecznym ludzkości nazwano społeczeństwem informacyjnym. W wyniku postępu w rozwoju technik i technologii komputerowych mamy do czynienia $\mathrm{z}$ rewolucją $\mathrm{w}$ dziedzinie przechowywania, przetwarzania i przesyłania informacji. Nowe technologie to najszybciej rozwijający się sektor gospodarki w krajach rozwiniętych, mający coraz większy udział w ich PKB. Obserwujemy intensywny rozwój sieci cyfrowych i Internetu. Wraz z Internetem zminimalizowano czas potrzebny na przepływ informacji, odległość przestała grać rolę w kontaktach biznesowych, pojawiają się nowe produkty dzięki możliwościom stwarzanym przez nowe technologie. Społeczeństwo informacyjne ma specyficzne cechy, istnieje w świecie z rosnącym znaczeniem informacji, wiedzy i innowacyjności, z powszechnym wykorzystaniem technologii teleinformatycznych, rosnącą liczbą pracowników związanych z szeroko rozumianą informacją. Kluczowym czynnikiem jego rozwoju jest $\mathrm{z}$ jednej strony stale rosnąca moc obliczeniowa komputerów, $\mathrm{z}$ drugiej ich malejąca cena. Sieci komputerowe pozwalają na łatwą wymianę danych i samej mocy obliczeniowej, stając się sednem społeczeństwa informacyjnego. Autorstwo pojęcia „społeczeństwo informacyjne” przypisuje się D. Bellowi (Bell 1973). Wskazał on na takie cechy nowej struktury społecznej, jak: dominacja sektora usług, rozwój sektora czwartego (finanse, ubezpieczenia) i piątego (zdrowie, oświata, nauka), rosnące znaczenie specjalistów, naukowców wiedzy teoretycznej, nastawienie na rozwój techniki ${ }^{1}$.

Społeczeństwo informacyjne to takie, w którym tworzenie, dystrybucja i przetwarzanie informacji to najważniejsze wyznaczniki społeczeństwa. Jego ekonomiczny odpowiednik to gospodarka oparta na wiedzy, w której dobrobyt jest tworzony przez eksploatację wiedzy (Castells, Himanen 2003). Gospodarka oparta na wiedzy najczęściej kojarzona jest ze wszystkim, co związane jest z technologiami informa(2008).

Interesujący przegląd definicji społeczeństwa informacyjnego zamieszczono w: Nowak 
cyjno-komunikacyjnymi, postępem technicznym i innowacyjnością. Koncepcja gospodarki opartej na wiedzy zakłada, że głównym czynnikiem rozwoju i kształtowania się nowych struktur gospodarki staje się wiedza, a tradycyjne czynniki produkcji: ziemia i zasoby naturalne, praca i kapitał, ustępują jej miejsca (Kukliński 2003). Podstawę rozwoju gospodarki opartej na wiedzy upatruje się w rosnącym znaczeniu globalizacji oraz rozwoju technik informatycznych. Według autorów raportu OECD gospodarka oparta na wiedzy to taka, która bezpośrednio bazuje na produkcji, dystrybucji oraz stosowaniu wiedzy i informacji (OECD 1999). Upowszechnienie technologii informacyjno-komunikacyjnych jest jednym z istotnych czynników rozwoju gospodarki opartej na wiedzy. Wykorzystanie nowych technologii stwarza większe możliwości, przynosi pozytywne efekty, a niejednokrotnie jest niezbędne w życiu codziennym, w komunikacji, nauce, pracy, dostępie do informacji i wiedzy. Wzrost znaczenia komputerów i Internetu obserwujemy we wszystkich sferach życia.

Podstawy gospodarki opartej na wiedzy (GOW) tworzą trendy: wzrostu znaczenia sfery usług i inwestycji w aktywa niematerialne, upowszechnienia nowych technologii informacyjno-komunikacyjnych oraz budowy społeczeństwa informacyjnego, a także nowe wymagania i podejście do wiedzy w uczących się organizacjach (Platonoff, Sysko-Romańczuk, Moszoro 2004). GOW to nowa gospodarka, którą cechuje dominujący udział sektora usług w wytwarzaniu PKB i zatrudnieniu, a oparta jest ona na wszechstronnym wykorzystaniu wiedzy i informacji. Ponadto bardzo popularne są pojęcia: „gospodarka postindustrialna”, wprowadzona w pracy D. Bella (1973), zaproponowana przez A. Tofflera (1999) „trzecia fala”, określenia „gospodarka usługowa” i ,cywilizacja tercjalna”, w których podkreśla się dominację trzeciego sektora w produkcji i zatrudnieniu, ,gospodarka elementów niematerialnych” oraz ,gospodarka cyfrowa”, „gospodarka sieciowa” i „społeczeństwo informacyjne", podkreślające rolę informacji i jej nośników.

Gospodarkę opartą na wiedzy wyróżniają charakterystyczne cechy, do których należą m.in. zmienność bliższego i dalszego otoczenia, konieczność zdobywania i wykorzystywania wiedzy, potrzeba przemiany społeczeństwa przemysłowego w informacyjne, uzależnienie zdolności przeżycia organizacji od dostępu do informacji oraz umiejętnego ich przetwarzania i adaptacji do zmian, ponadto konieczność globalnego spojrzenia na gospodarkę, rynek, ochronę środowiska oraz dostrzeżenie rosnącej roli zasobów niematerialnych, tj. wiedzy, kapitału intelektualnego i informacji (Skrzypek 2009). Gospodarka oparta na wiedzy jest charakteryzowana przez poziom 
produkcji, zatrudnienia w wyszczególnionych sektorach wysokiej techniki opartych na wiedzy lub ICT czy szerzej: w sektorze informacyjnym, a więc obejmującym działalności służące produkcji, użytkowaniu, ochronie, gromadzeniu, przechowywaniu, przekazywaniu i przesyłaniu informacji (Dziuba 2010). Swoistymi nośnikami gospodarki opartej na wiedzy są: przemysł wysokiej techniki, usługi oparte na wiedzy, edukacja i powszechny, nieograniczony dostęp do informacji i wiedzy.

\section{Rozwój i rozpowszechnienie się ICT w gospodarce i społeczeństwie}

Zasadniczym czynnikiem wzrostu dobrobytu jest wydajność. W uproszeniu wydajniejsi pracownicy zarabiają więcej, doświadczają wyższego poziomu życia. Wiele badań naukowych wskazuje, że powodem istotnych różnic między krajami $\mathrm{w}$ zakresie wzrostu gospodarczego $\mathrm{w}$ ostatnich latach były różnice w inwestycjach w dziedzinie technologii informacyjno-komunikacyjnych. Wykorzystanie ICT powszechnie uznawane jest za kluczowy czynnik poprawy konkurencyjności gospodarki.

Technologie te dotykają również wielu aspektów życia społecznego, zarówno zawodowych, jak i osobistych. Ich istotna rola jako technologii ogólnego przeznaczenia zaznacza się $\mathrm{w}$ tak wielu sferach życia, że trudno byłoby je wyliczyć. Wykorzystanie ICT jest jednym z głównych czynników wpływających na zmiany zachodzące w domu i w pracy przez kilka ostatnich dziesięcioleci. Dość stwierdzić, że znaczenie ICT podkreślane jest $\mathrm{w}$ dokumentach określających polityki od przemysłowej i sektorowej po polityki prywatności i ochrony danych osobowych. Można przewidywać, a przynajmniej takie wyraża się nadzieje, że szybki wzrost we wszystkich formach komunikacji między ludźmi i urządzeniami (Internet of things) może przyczynić się do dalszego wzrostu dobrobytu.

Rozpowszechnianie się technologii informacyjno-komunikacyjnych jest przedmiotem wielu badań naukowych, w tym badań statystycznych. Istnieje szerokie spektrum opracowań na poziomach narodowych i międzynarodowych dotyczących kwestii pomiaru rozwoju społeczeństwa informacyjnego, przygotowywanych przez narodowe instytuty statystyczne oraz organizacje międzynarodowe (patrz np. Rozkrut 2014; OECD 2015). Publikacje te regularnie wskazują na ciągły postęp w dziedzinie wykorzystania coraz to nowszych i bardziej zaawansowanych technologii informacyjno-komunikacyjnych w gospodarce i społeczeństwie. 
U podstaw rozprzestrzeniania się ICT we wszystkich domenach życia społeczno-gospodarczego leży dynamiczny postęp technologiczny, przyczyniający się do systematycznego spadku cen tych technologii, chociażby w odniesieniu do pamięci masowych i mocy obliczeniowej, co ułatwia stały wzrost inwestycji. Choć jednak łatwo wskazać na korzyści z takiego stanu rzeczy, odnoszące się przede wszystkim do wzrostu wydajności pracy, nie można nie zauważyć krótkookresowego negatywnego wpływu na wybrane wskaźniki ekonomiczne, związanego z silną presją na wzrost umiejętności pracowników i zdolności adaptacji do nowych warunków pracy. Badania OECD wskazują, że od 2007 roku w gospodarkach krajów rozwiniętych dodatniemu trendowi w zakresie wydajności pracy towarzyszył negatywny wpływ na zatrudnienie. Mimo że przewidywania teoretyczne w tej kwestii podkreślają, że sytuacja ta $\mathrm{z}$ czasem powinna ulec poprawie, wskazuje się na potrzebę budowy polityk wspierających zatrudnienie, regulując rynki pracy.

Wykorzystanie ICT w pracy powoduje wzrost oczekiwań odnośnie do umiejętności pracowników. Dotyczy to prostych, ogólnych umiejętności związanych w codziennym korzystaniem i podstawową wiedzą na temat oprogramowania, komunikacji elektronicznej. Coraz częściej jednak wymagania te rosną, rośnie popyt na osoby z umiejętnościami komplementarnymi (komunikacja na platformach społecznościowych, marketing na platformach cyfrowych itp.) czy specjalistycznymi (programowanie, rozwój aplikacji, administracja sieciami). Mimo wzrostu wykorzystania ICT w życiu codziennym obserwuje się niedopasowanie lub co najmniej trudności w dopasowaniu umiejętności oferowanych na rynku pracy z popytem przedsiębiorstw. Sytuacja ta może ulegać pogorszeniu wraz ze wzrostem wymagań na rynku pracy. Niewątpliwie wymaga to budowy i wdrażania polityk wzrostu kompetencji cyfrowych.

\section{Kompetencje cyfrowe}

Kompetencje cyfrowe, do których zaliczamy umiejętności warunkujące efektywne korzystanie $\mathrm{z}$ mediów elektronicznych, to szeroki zbiór umiejętności warunkujących sprawne i świadome korzystanie z nowych technologii oraz aktywne uczestnictwo w życiu społeczeństwa informacyjnego. Nie ograniczają się one tylko do obsługi samego sprzętu, ale obejmują również umiejętności informacyjne, docierania do nowych informacji z różnych źródeł i wykorzystywania ich, poszerza- 
nia swojej wiedzy za pomocą ICT. Kompetencje cyfrowe umożliwiają stały rozwój, zwiększają możliwości społeczeństwa w dostosowywaniu się do zmian na rynku pracy. Rozwój kompetencji cyfrowych w społeczeństwie ma istotny wpływ na rozwój gospodarki opartej na wiedzy, zwiększa jej innowacyjność i konkurencyjność. Istotne są również kompetencje informatyczne, które stanowią zespół umiejętności, postaw i wiedzy niezbędnych, by rozumieć podstawowe funkcje ICT oraz z nich skorzystać, włączając w to takie urządzania, jak: komputery osobiste, laptopy, tablety, telefony komórkowe, smartfony (Horton 2007). Niejednokrotnie kompetencje informatyczne mylone są z kompetencjami informacyjnymi, które pozwalają użytkownikom wyszukać, ocenić i umiejętnie wykorzystać informacje pochodzące z różnych źródeł (Batorski, Płoszaj 2012).

Umiejętności cyfrowe i szerokie ich wykorzystywanie przez społeczeństwo są szansą dalszego rozwoju gospodarki i umożliwiają wzrost jej konkurencyjności. Zwiększają dostęp do wiedzy i informacji, upowszechniają zdobywanie umiejętności niezbędnych we wszystkich okresach życia i obszarach aktywności społecznej oraz zawodowej. Umiejętności cyfrowe są niezbędne w skutecznym korzystaniu z mediów cyfrowych w celach zawodowych, edukacyjnych i rekreacyjnych. Polegają one na możliwości korzystania z mediów cyfrowych, zdolności rozumienia i krytycznej oceny różnych aspektów tych mediów i ich treści oraz zdolności efektywnej komunikacji w różnych kontekstach. Bez podstawowych kompetencji cyfrowych trudno jest brać pełny udział w życiu społecznym. Powszechność stosowania i stopień zaawansowania umiejętności cyfrowych społeczeństwa stają się wyznacznikiem dynamiki rozwoju gospodarki.

Umiejętności cyfrowe podlegają ciągłym zmianom. Dotrzymanie kroku tym zmianom wymaga uczenia się przez całe życie, nabycia umiejętności innowacyjnego i efektywnego korzystania z możliwości, jakie dają sieci i media cyfrowe. Wyniki badań szeroko pojętych umiejętności cyfrowych prezentowane są w opracowaniach GUS (patrz np. Rozkrut 2014). Badania te realizowane są zgodnie z zaleceniami metodologicznymi stosowanymi w krajach OECD i UE.

Pojawienie się i rozwój nowych technologii cyfrowych nie są zatem obojętne dla rynku pracy. Nowe rozwiązania, które powstają w wyniku automatyzacji i zwiększania efektywności, przyczyniają się do pojawiania się nowych zawodów, które zastępują część istniejących. W warunkach tak dynamicznego rozpowszechniania się technologii informacyjno-komunikacyjnych umiejętności cyfrowe prze- 
stają być domeną specjalistycznej kadry informatycznej. W istocie ostatnie badania OECD w tym zakresie wskazują, że spośród dwudziestu zawodów najintensywniej wykorzystujących ICT piętnaście nie dotyczy specjalistów w zakresie ICT. Podstawowe umiejętności wymagane są już niemal w każdej dziedzinie życia, podobnie też w pracy. Technologie informacyjno-komunikacyjne zmieniają sposób, w jaki pracujemy, stąd wymagania co do umiejętności obejmują coraz to szerszy zakres czynności związanych z większą częstotliwością sięgania do informacji, zdolnością planowania, szybszego dostosowywania się do zmieniających warunków, a także umiejętności współpracy w organizacjach horyzontalnych, szybkiej wymiany informacji i dzielenia się wiedzą między pracownikami.

Badania prowadzone przez OECD w zakresie umiejętności osób dorosłych wskazują na stopniową, regularną poprawę w zakresie podstawowych umiejętności cyfrowych. Podobne wyniki kształtują się w zharmonizowanych badaniach wskaźników społeczeństwa informacyjnego prowadzonych w krajach Unii Europejskiej (Rozkrut 2014). Niemniej w wielu krajach istnieją znaczne niedobory w tym zakresie. Odnotowuje się również wyraźną korelację odsetka osób bez doświadczeń w wykorzystaniu ICT w pracy z innymi wskaźnikami rozwoju gospodarki opartej na wiedzy. Popyt na pracowników o umiejętnościach bardziej zaawansowanych w ostatnich latach szybko rośnie. Istnieje obawa, że rynek może napotkać niedobory $\mathrm{w}$ tym zakresie, które z jednej strony powodować będą relatywny wzrost wynagrodzeń tej grupy pracowników, z drugiej mogą okazać się barierą rozwoju.

Kompetencje ICT są niezbędne do uczestnictwa w coraz bardziej zdigitalizowanym społeczeństwie. W tym kontekście pomiar i oceny kompetencji ICT są bardzo ważne z punktu widzenia budowy skutecznych polityk społecznych. Analiza umiejętności cyfrowych wymaga sformułowania ogólnych ram kompetencji. Wiele spośród zaproponowanych dotychczas ram oceny kompetencji koncentruje się na konkretnych zestawach umiejętności. Europejska agenda cyfrowa (EAC) (Komunikat Komisji 2010) postuluje standard DIGICOMP (Ferrari 2013), opracowany razem ze Wspólnym Centrum Badawczym (JRC) na potrzeby polityk UE posługujących się wskaźnikami umiejętności cyfrowych. Standard DIGICOMP wskazuje 21 kompetencji i przedstawia je w wymiarach wiedzy, umiejętności i postaw. Tak określony standard wykorzystany może być do oceny cyfrowych kompetencji osób. W dokumencie przedstawiono szczegółowe opisy kompetencji potrzebnych w środowisku cyfrowym. Zaawansowanie kompetencji ocenia się według trzystopniowej skali: 
kompetencji podstawowych, średnich i zaawansowanych. Zharmonizowane badania prowadzone w krajach członkowskich UE dostarczają wielu statystyk odnośnie do umiejętności cyfrowych, opartych przede wszystkim na pytaniach dotyczących różnych rodzajów aktywności użytkowników. Wyniki tych badań są szeroko prezentowane $\mathrm{w}$ wielu dokumentach programowych na poziomie narodowym i międzynarodowym. Ramy oceny kompetencji DIGICOMP wskazują na sposób mapowania tych wskaźników z proponowanymi rodzajami kompetencji. Wydaje się, że od strony pomiaru statystycznego istnieje wiele bogatych źródeł informacji na temat umiejętności cyfrowych, zarówno na poziomie krajowym, jak i międzynarodowym.

\section{Potrzeby w zakresie ksztaltowania polityki dla umiejętności cyfrowych}

Umiejętności w zakresie informacji, mediów, technologii informacyjno-komunikacyjnych, danych, korzystania z sieci, e-zdrowia odgrywają ważną rolę w kształtowaniu zdolności człowieka do wykonywania zadań związanych z edukacją, pracą, kulturą, życiem. Te obszary kompetencyjne związane są ze zdolnościami poznawczymi niezbędnymi do krytycznego myślenia. Niestety badania wskazują, że wiele osób znajduje się w tym względzie w niekorzystnej sytuacji, co stanowi o wadze tego problemu jako istotnej kwestii polityki rozwoju społeczno-gospodarczego. W istocie umiejętności cyfrowe wymieniane są wśród najważniejszych zagadnień i celów polityki na rzecz rozwoju gospodarki cyfrowej, takich jak: gospodarcze i społeczne korzyści płynące z otwartego Internetu, pobudzanie innowacji związanych z ICT, poprawa stanu sieci komunikacyjnych, Internet rzeczy, zaufanie, bezpieczeństwo cyfrowe i ochrona prywatności.

Brak odpowiednich umiejętności cyfrowych naraża na wykluczenie społeczne. Wykluczenie to może mieć różne przyczyny: brak lub utrudniony dostęp, niekorzystanie z ICT lub niskie umiejętności korzystania ${ }^{2}$. Komisja Europejska ocenia, że niemal połowa populacji UE nie ma wystarczających umiejętności cyfrowych, mimo że w najbliższej przyszłości niemal wszystkie stanowiska pracy będą wymagały przynajmniej podstawowych umiejętności. Stąd też jedną z flagowych inicjatyw KE jest jednolity rynek cyfrowy i powiązane z nim zadania: zapewnienia wzro-

2 Badania wskazują, że Internet $\mathrm{i}$ korzystanie z niego coraz bardziej odzwierciedlać będą istniejące relacje społeczne, gospodarcze i kulturowe, nierówności obserwowane w świecie rzeczywistym (offline). Więcej na ten temat patrz: Deursen, Dijk (2014). 
stu gospodarczego, tworzenia nowych miejsc pracy przez inicjatywy legislacyjne dotyczące ochrony danych i zakupów konsumenckich, rozpowszechnienia i wzrostu umiejętności cyfrowych, zdolności do uczenia się czy ułatwienia tworzenia innowacyjnych start-upów. Wykorzystanie technologii cyfrowych i usług internetowych, obejmujące wszystkie sektory gospodarki i sektora publicznego, staje się zasadniczym elementem polityki.

Wszystkie te inicjatywy są częścią horyzontalnej polityki prowadzonej pod hasłem Europejskiej agendy cyfrowej, która jest pierwszą z inicjatyw przewodnich strategii Europa 2020 - strategii UE na rzecz inteligentnego i zrównoważonego rozwoju. Agenda ustanawia ambitny plan działania w siedmiu priorytetowych obszarach: stworzenie jednolitego rynku cyfrowego, interoperacyjność, zaufanie do Internetu i bezpieczeństwo, szybki dostęp do Internetu, umiejętności informatyczne i integracja społeczna, inwestycje w badania i rozwój oraz technologie informacyjno-komunikacyjne. W 2012 roku Komisja Europejska dokonała przeglądu agendy cyfrowej, identyfikując siedem obszarów dla nowych inicjatyw związanych z gospodarką cyfrową, tj. rozwiązania szerokopasmowe, publiczne otoczenie regulacyjne infrastruktury usług cyfrowych, umiejętności cyfrowe i zatrudnienie, cyberbezpieczeństwo, prawa autorskie, przetwarzanie w chmurze i przemysł elektroniczny. Warto odnotować rolę problematyki umiejętności cyfrowych, systematycznie wskazywanych we wszystkich powiązanych dokumentach programowych. Znaczenie e-umiejętności i kompetencji ICT podkreślono w inicjatywie przewodniej - w Programie na rzecz nowych umiejętności i zatrudnienia oraz Liście zadań: nowe priorytety cyfrowe w latach 2013-2014³ zmierzających do maksymalizacji wpływu sektora cyfrowego na ożywienie gospodarcze w Europie.

\section{Podsumowanie}

Zwiększenie wykorzystania technologii informacyjno-komunikacyjnych w pracy oznacza zwiększenie zapotrzebowania na nowe umiejętności. Wyróżnić należy trzy zasadnicze grupy: po pierwsze, specjalistyczne umiejętności ICT, takie jak programowanie, po drugie, tworzenie aplikacji, zarządzanie sieciami, ogólne umiejętności ICT pozwalające korzystać z nowych technologii w codziennej pracy, takie jak umiejętność pozyskiwania informacji online czy korzystania z oprogramowania,

\footnotetext{
3 An Agenda for new skills and jobs; Digital to-do list: new digital priorities 2013-2014.
} 
po trzecie wreszcie, nie mniej istotne umiejętności komplementarne, takie jak rozwiązywanie problemów, praca zespołowa, komunikacja, negocjacje, tj. umiejętności ważne w środowisku, w którym nowe technologie informacyjno-komunikacyjne zmieniają sposób wykonywania zawodu, pracy.

Zmiany w zakresie zapotrzebowania na umiejętności stanowią z jednej strony poważne wyzwania dla systemu edukacji, z drugiej są szansą na nowe możliwości, poprawę nauki w szkole i poza nią, dzięki np. otwartym platformom edukacyjnym, dostępowi do wysokiej jakości zasobów. Aby zaspokoić zapotrzebowanie na nowe umiejętności w gospodarce cyfrowej, potrzeba umiejętnego określania odpowiedniej polityki. Niedobory i niedopasowanie umiejętności mogą mieć bowiem wiele negatywnych skutków; w przypadku krajów i ich gospodarek: niską wydajność oraz niższą produkcję, niedostatecznie wykorzystany kapitał ludzki, zwiększone koszty pracy, zwiększone koszty szkoleń. Z perspektywy pracowników są to: niższe zarobki, mniejsza satysfakcja z pracy, wyższe ryzyko bezrobocia.

Zdolność do wczesnej identyfikacji niedoborów i niedopasowania w zakresie umiejętności cyfrowych staje się więc istotnym zagadnieniem polityki rozwoju społeczno-gospodarczego. Zasadniczym zadaniem jest systematyczna ocena umiejętności cyfrowych społeczeństwa oraz prowadzenia ćwiczeń antycypujących rozwój sytuacji na rynku pracy. Praktyczna realizacja takich zadań wymaga zaangażowania wszystkich potencjalnych interesariuszy, którzy mogą wskazać na specyficzne potrzeby w zakresie polityk, budowy mechanizmów dialogu z interesariuszami, zarówno formalnych, jak i nieformalnych, a także zapewnienia zaangażowania na najwyższych szczeblach polityki.

\section{Literatura}

Batorski D., Płoszaj A. (2012), Diagnoza i rekomendacje w obszarze kompetencji cyfrowych spoleczeństwa i przeciwdziałania wykluczeniu cyfrowemu w kontekście zaprogramowania wsparcia w latach 2014-2020, Ministerstwo Rozwoju Regionalnego, Warszawa.

Bell D. (1973), The Coming of Post-Industrial Society, Basic Books, New York.

Castells M., Himanen P. (2003), The Information Society and the Welfare State: The Finnish Model, Oxford University Press, Oxford. 
Dziuba D.T. (2010), Sektor informacyjny w badaniach ekonomicznych. Elementy ekonomiki sektora informacyjnego, Difin, Warszawa.

Deursen A.J.A.M. van, Dijk J.A.G.M. van (2014), The Digital Divide Shifts to Differences in Usage, „New Media \& Society”, vol. 16, nr 3.

Ferrari A. (2013), DIGCOMP: A Framework for Developing and Understanding Digital Competence in Europe, JRC Scientific and Policy Reports, Publications Office of the European Union, Luxembourg.

Horton jr. F.W. (2007), Understanding information literacy: a primer, UNESCO, Paris.

Komunikat Komisji do Parlamentu Europejskiego, Rady, Europejskiego Komitetu Ekonomiczno-Społecznego i Komitetu Regionów (2010), Europejska agenda cyfrowa (COM/2010/0245 f/2).

Kukliński A. (red.) (2003), Gospodarka oparta na wiedzy. Perspektywy Banku Światowego, Biuro Banku Światowego w Polsce, Komitet Badań Naukowych, Warszawa.

MacKay K., Vogt Ch. (2012), Information Technology in Everyday and Vacation Contexts, „Annals of Tourism Research”, vol. 39, nr 3.

Nowak J.S. (2008), Społeczeństwo informacyjne - geneza i definicje, w: Społeczeństwo informacyjne. Krok naprzód, dwa kroki wstecz, red. P. Sienkiewicz, J.S. Nowak, Polskie Towarzystwo Informatyczne - Oddział Górnośląski, Katowice.

OECD (1999), The Future of the Global Economy. Towards a Long Boom?, OECD, Paris.

OECD (2015), OECD Digital Economy Outlook 2015, OECD Publishing, Paris.

Platonoff A.L., Sysko-Romańczuk S., Moszoro B. (2004), Innowacyjność polskich firm w gospodarce opartej na wiedzy, „Ekonomika i Organizacja Przedsiębiorstw”, nr 1.

Presidential Committee on Information Literacy: Final Report (1989), http://www.ala.org/ ala/mgrps/divs/acrl/publications/whitepapers/presidential.cfm (2.04.2015).

Rozkrut D. (red.) (2014), Społeczeństwo informacyjne w Polsce. Wyniki badań statystycznych z lat 2010-2014, Główny Urząd Statystyczny, Warszawa.

Skrzypek E. (red.) (2009), Kapitat intelektualny w organizacji, Wydawnictwo UMCS, Lublin 2009.

Toffler A. (1999), Trzecia fala, Wydawnictwo Naukowe PWN, Warszawa 1999. 


\title{
DIGITAL SKILLS AS A FACTOR OF KNOWLEDGE-BASED ECONOMY GROWTH
}

\begin{abstract}
Progress in the development of information and communication technologies leads to significant changes in the socio-economic system. Thanks to the revolution in the field of storage, processing and transmission of information, today we use the concepts of information society or knowledge-based economy to refer to or describe socio-economic system. Knowledge-based economy is characterized by extensive use of knowledge and information. This poses serious challenges in the field of digital skills, as these are becoming more desirable in the labour market but also increasingly necessary in everyday life. Lack of these skills, their inadequate level or mismatch are detrimental to economic growth.
\end{abstract}

Translated by Dominik Rozkrut

Keywords: knowledge-based economy, e-skills, information society, digital divide JEL Codes: J24, J28, O33 
